20. Ivanova R, Henon N, Lepage V, et al. HLA-DR alleles display sex-dependent effects on survival and discriminate between individual and familial longevity. Hum Mol Genet 1998;7:187-194.

21. Woolf B. On estimating the relation between blood group and disease. Ann Eugen 1955;19:251-253.

22. Lewontin RC. The detection of linkage disequilibrium in molecular sequence data. Genetics 1995;140:377-388.

23. Payami H, Joe S, Farid NR, et al. Relative predispositional effects (RPEs) of marker alleles with disease: HLA-DR alleles and Graves disease. Am J Hum Genet 1989;45:541-546.

24. Spielman RS, McGinnis RE, Ewens WJ. Transmission test for linkage disequilibrium: the insulin gene region and insulindependent diabetes mellitus (IDDM). Am J Hum Genet 1993; 52:506-516.

25. Kruglyak L, Daly MJ, Reeve-Daly MP, et al. Parametric and nonparametric linkage analysis: a unified multipoint approach. Am J Hum Genet 1996;58:1347-1363.

26. Sham PC, Curtis D. An extended transmission/disequilibrium test (TDT) for multi-allele marker loci. Ann Hum Genet 1995; 59:323-336.

27. Hoch W, McConville J, Helms S, Newsom-Davis J, Melms A, Vincent A. Autoantibodies to the receptor tyrosine kinase
MuSK in patients with myasthenia gravis without acetylcholine receptor antibodies. Nat Med 2001;7:365-368.

28. Kruglyak L, Lander E. Genetic dissection of complex traits: guidelines for interpreting and reporting linkage results. Nat Genet 1995;11:241-247.

29. Degli-Esposti MA, Andreas A, Christiansen FT, et al. An approach to the localization of the susceptibility genes for generalized myasthenia gravis by mapping recombinant ancestral haplotypes. Immunogenetics 1992;35:355-364.

30. Janer M, Cowland A, Picard J, et al. A susceptibility region for myasthenia gravis extending into the HLA-class I sector telomeric to HLA-C. Hum Immunol 1999;60:909-917.

31. Matsuki K, Juji T, Tokunaga K, et al. HLA antigens in Japanese patients with myasthenia gravis. J Clin Invest 1990;86: 392-399.

32. Muller-Hermelink HK, Marx A. Pathological aspects of malignant and benign thymic disorders. Ann Med 1999;31(suppl 2):5-14.

33. Spielman RS, Ewens WJ. A sibship test for linkage in the presence of association: the sib transmission/disequilibrium test. Am J Hum Genet 1998;62:450-458.

\title{
Neurolmages
}
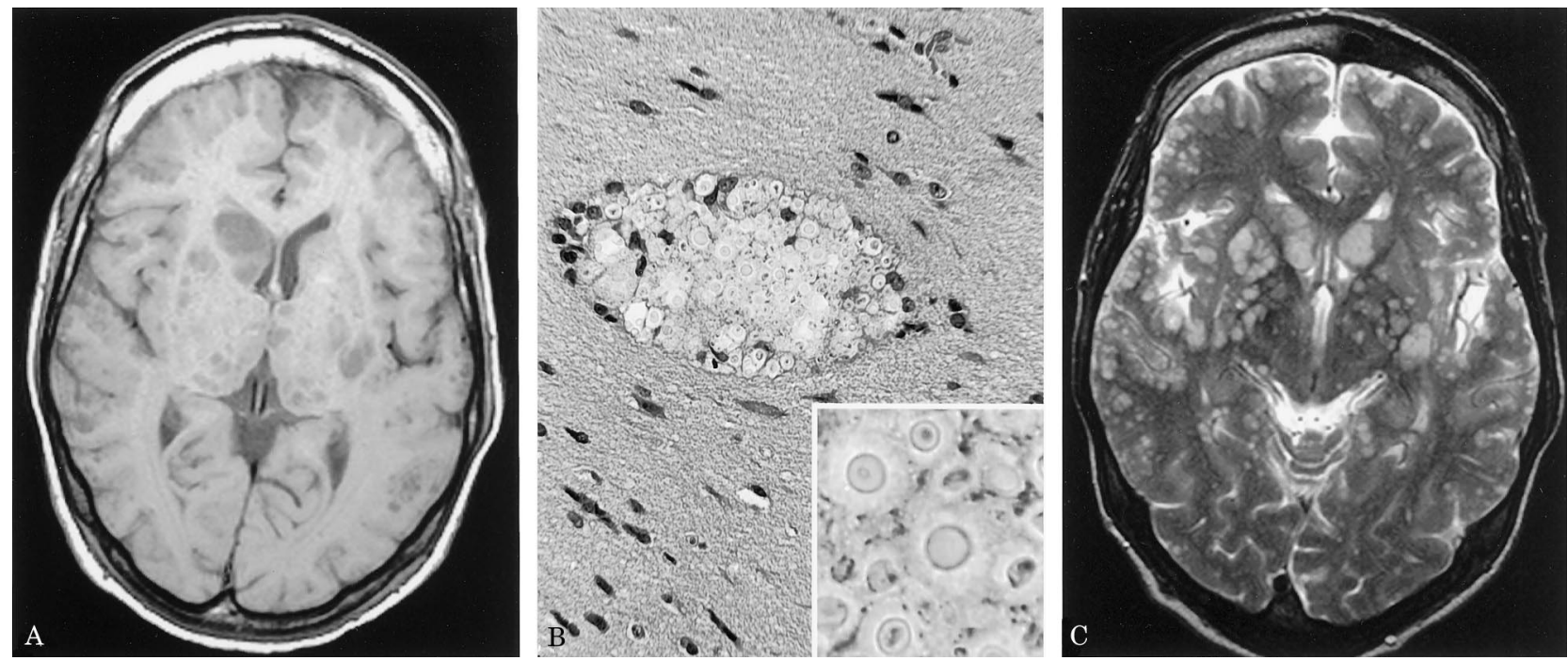

Figure. (A) T1-weighted MRI; mixed pattern of CNS cryptococcus. (B) Virchow-Robin space crowded with cryptococci (hematoxylin and eosin, $\times 400$ before reduction). Inset: cryptococcus neoformans with the mucinous capsule (hematoxylin and eosin $\times 1,000$ before reduction). (C) T2-weighted MRI; mucoid material within Virchow-Robin spaces. Gelatinous pseudocysts in the head of the caudate and putamen.

\section{Overwhelming CNS cryptococcus in AIDS}

H.M. Bos, MD, P.A.M. Hofman, MD, PhD, G. Schreij, MD, PhD, F.J. Bot, MD, PhD, R.J. van Oostenbruggen, $M D, P h D$, Maastricht, the Netherlands

A 46-year-old HIV-positive man $\left(\mathrm{CD}_{4}\right.$ count 6 cells $/ \mathrm{mL}$, plasma HIV load $346 \times 10^{3}$ copies $/ \mathrm{mL}$ ) presented with a subacute onset of confusion. Neurologic examination demonstrated meningeal irritation. CT examination showed no abnormailities. CSF analysis revealed a cryptococcal infection. Because the patient deteriorated despite treatment, an MRI scan was performed 4 weeks later. The images showed a mixed pattern of dilated Virchow-Robin spaces filled with mucoid material, ${ }^{1}$ gelatinous pseudocysts in the head of the caudate and putamen, ${ }^{2}$ and widespread parenchymal and leptomeningeal nodules ${ }^{2}$ (figure, $\mathrm{A}$ and $\mathrm{C}$ ).
This is a classical example of a mixed pattern of CNS cryptococcus in a patient with AIDS. Histopathologic analysis showed a dilated Virchow-Robin space, crowded with cryptococci (hematoxylin and eosin, $\times 400$; see the figure, B). Typically, no inflammation reaction and only limited gliosis in the surrounding nervous tissue was seen. The inset in figure B shows cryptococcus neoformans with the cell wall (dark) surrounded by a clear space representing the mucinous capsule (hematoxylin and eosin, $\times 1,000$; see the figure, B). The patient died 2 months after receiving intensive antifungal therapy.

1. Mathews VP, Alo PL, Glass JD, Kumar AJ, McArthur JC. AIDS-related CNS cryptococcosis: radiologic-pathologic correlation. AJNR Am J Neuroradiol 1992;13:1477-1486.

2. Tien RD, Chu PK, Hesselink JR, Duberg A, Wiley C. Intracranial cryptococcosis in immunocompromised patients: CT and MR findings in 29 cases. AJNR Am J Neuroradiol 1991;12:283-289. 


\section{Neurology}

\section{Overwhelming CNS cryptococcus in AIDS}

H. M. Bos, P. A.M. Hofman, G. Schreij, et al.

Neurology 2001;57;1560

DOI 10.1212/WNL.57.9.1560

This information is current as of November 13, 2001

\section{Updated Information \& Services}

References

Permissions \& Licensing

Reprints including high resolution figures, can be found at: http://n.neurology.org/content/57/9/1560.full

This article cites 2 articles, 2 of which you can access for free at: http://n.neurology.org/content/57/9/1560.full\#ref-list-1

Information about reproducing this article in parts (figures,tables) or in its entirety can be found online at:

http://www.neurology.org/about/about_the_journal\#permissions

Information about ordering reprints can be found online:

http://n.neurology.org/subscribers/advertise

Neurology ${ }^{\circledR}$ is the official journal of the American Academy of Neurology. Published continuously since 1951, it is now a weekly with 48 issues per year. Copyright . All rights reserved. Print ISSN: 0028-3878.

Online ISSN: 1526-632X.

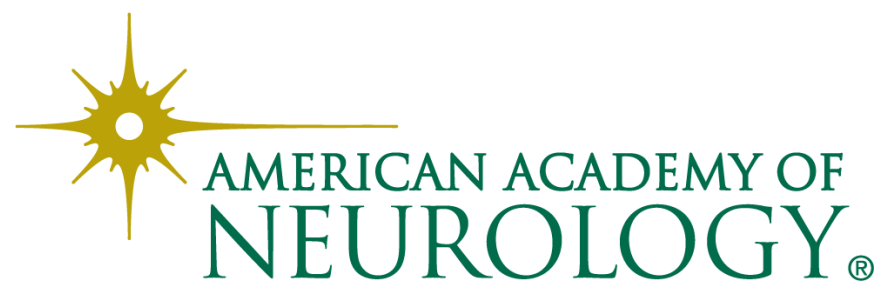

